\title{
The potential role of recombinant hematopoietic colony-stimulating factors in preventing infections in the immunocompromised host
}

JAMES RUSTHOVEN, MD, FRCPC, FACP

\begin{abstract}
J RUSTHOVEN. The potential role of recombinant hematopoietic colony-stimulating factors in preventing infections in the immunocompromised host. Can $J$ Infect Dis 1991;2(2):74-88. Hematopoietic colony-stimulating factors coordinate the proliferation and maturation of bone marrow and peripheral blood cells during normal hematopoiesis. Most of these factors are now available as recombinant human colony-stimulating factors, and preclinical and clinical testing is proceeding rapidly. Granulocyte and granulocyte/macrophage colony-stimulating factors have been the most extensively studied to date. In human clinical trials, granulocyte colony-stimulating factor improves neutrophil counts and function, reduces episodes of febrile neutropenia, improves neutrophil recovery after disease- or treatment-induced myelosuppression, and reduces the number of serious infections in several neutropenic disease states. Granulocyte/macrophage colony-stimulating factor has similar biological properties but may also improve eosinophil proliferation and function, and platelet cell recovery after myelotoxic bone marrow injury. Interleukin-1 boosts the effects of granulocyte colonystimulating factor and granulocyte/macrophage colony-stimulating factor, but also may promote the resolution of established infections in conjunction with antibiotics. The therapeutic realities and future therapeutic implications of these agents for the therapy of infections, cancer and hemopoietic disorders are discussed.
\end{abstract}

Key Words: Colony-stimulating factors, Febrile neutropenia. Hematopoiesis, Neutropenia

\section{Rôle potentiel des facteurs recombinants stimulant les colonies hématopoïétiques dans la prévention des infections chez l'hôte immunodéprimé}

RESUME: Les facteurs stimulant les colonies hématopoïétiques coordonnent la prolifération et la maturation des cellules de la moelle osseuse et du sang périphérique au cours de l'hématopoïèse normale. La plupart de ces facteurs connus sous le nom de "facteurs stimulant les colonies" font actuellement l'objet d'évaluations précliniques et cliniques qui progressent

Hamilton Regional Cancer Centre, Hamilton, Ontario

Correspondence and reprints: Dr J Rusthoven, Hamilton Regional Cancer Centre, 711 Concession Street. Hamilton, Ontario LSV 1C3. Telephone (416) 387-9495 ext 4341

Received for publication July 27. 1990. Accepted October 15, 1990 
rapidement. Les facteurs stimulant les colonies de granulocytes et de granulocytes macrophages ont été les plus étudiés jusqu'à présent. Au cours des études chez l'homme, le facteur stimulant les colonies de granulocytes augmente le taux et la fonction des polynucléaires neutrophiles, réduit les épisodes de neutropénie fébrile, accélère le retour à la normale des polynucléaires abaissés par la maladie ou une thérapie myélosuppressive, et réduit le nombre des infections graves dans plusieurs affections qui s'accompagnent de neutropénie. Le facteur stimulant les colonies de granulocytes macrophages a des propriétés biologiques similaires mais il pourrait aussi améliorer la prolifération et la fonction des éosinophiles et le retour à la normale des plaquettes après des lésions myélotoxiques de la moelle épinière. L'interleukine-1 majore les effets du facteur stimulant les colonies de granulocytes et ceux du facteur stimulant les colonies de granulocytes macrophages, mais il pourrait aussi promouvoir la résolution des infections établies de concert avec les antibiotiques. Les réalités thérapeutiques et les implications thérapeutiques futures de ces agents dans le traitement des infections, du cancer et des troubles hémopoïetiques sont examinées.

$\mathrm{T}$ HE 1990s PROMISE TO BE EXCITING YEARS IN THE clinical development of recombinant biological products. The medical disciplines on which these agents will likely have the greatest impact are hematology, oncology and infectious diseases. The clinical questions which are already being addressed through early clinical trials include those affecting the immunocompromised host. Of these promising new agents, the hematopoietic colony-stimulating factors (CSFs) have thus far been the most widely tested in this clinical setting and will be the subject of this review. Reference will be made to Canadian strategies and clinical trials for the development of these agents.

\section{REGULATION OF NORMAL HEMATOPOIESIS BY CSFS}

Under normal conditions in the human bone marrow, the CSFs regulate the expansion of a given hematopoietic cell lineage from the stem cell to the functionally mature peripheral blood cell (1). While some CSFs function primarily by stimulating the clonal proliferation of uncommitted progenitors (eg, interleukin-3), others induce both proliferation and differentiation along a functionally committed pathway (eg, granulocyte-CSF [G$\mathrm{CSF}]$ and erythropoietin). Furthermore. CSFs interact to induce synergistic hematopoietic responses, as well as to down-regulate each other's cell surface receptors $(2,3)$.

The term 'colony-stimulating factor' originated from early in vitro studies. Assays were developed which allowed for controlled growth of cell colonies derived from normal bone marrow. Each colony evolved from a single cell known as a 'colony-forming unit' (CFU). Different constituents or factors in the media were found to promote the growth of different colony types $(4,5)$. Thus, by manipulating these factors, different assays were developed whereby lineage-specific colonies could be studied. For example, the CFU-granulocyte/ macrophage assay promotes the growth of CFUs committed to granulocyte/macrophage maturation and function. In the CFU-mega assay, CFUs proliferate to form megakaryocyte colonies. Through painstaking purification procedures, each factor necessary to produce distinct types of colonies was identified in the 1970s. One of the last assays to be developed was that which detected a cell which could differentiate into erythrocytes, granulocytes, monocytes and megakaryocytes. However, this cell (the CFU-multiprogenitor cell) has minimal potential for self renewal. While the factors responsible for $\mathrm{CFU}$ proliferation can mimic hematopoiesis in vitro, the maintenance of prolonged hematopoiesis in vitro requires the addition of a stromal layer which produces yet other factors (4).

In addition to their effects on hematopoiesis, some CSFs have a broad range of immune functions. For example, granulocyte/macrophage-CSF (GM-CSF) induces the production of interleukin-1 and tumour necrosis factor (TNF) by peripheral blood mononuclear cells, and through the latter may stimulate monocyte cytotoxicity against tumour targets (6). GM-CSF also augments the monocyte/macrophage-mediated inhibition of intracellular Trypanosoma cruzi replication (7), and stimulates the killing of Leishmania tropica within murine macrophages (8).

While diversified in their effects on hematopoiesis, human CSFs have some striking similarities. All are glycoproteins, with the carbohydrate portion having little or no effect on biological function. The genes for CSFs are found close either to other CSFs or to other genes related to neutrophil function. Interleukin-3, GM-CSF, macrophage-CSF (M-CSF) and the receptor for M-CSF all lie on a restricted portion of chromosome 5. Deletion of this region is associated with the myelopoietic disorder known as the 5q-deletion syndrome (9). G-CSF, on the other hand, lies near the gene for myeloperoxidase located on chromosome 17 (10). Finally, all CSFs are produced from a variety of 
TABLE 1

Characteristics of human colony-stimulating factors (CSFs)

\begin{tabular}{|c|c|c|c|c|}
\hline Factor & Targets of action & Gene locus & Biological activities & References \\
\hline G-CSF & Neutrophil & $17 q$ & $\begin{array}{l}\text { Stimulates growth, maturation and activation of neutrophil colonies } \\
\text { and their cells in vitro } \\
\text { Augments neutrophil-mediated cytotoxicity } \\
\text { Induces differentiation of leukemia cell lines in vitro } \\
\text { Stimulates leukemic progenitor proliferation } \\
\text { Supports target cell survival }\end{array}$ & $\begin{array}{l}1,10,18,27-30 \\
35-39\end{array}$ \\
\hline GM-CSF & $\begin{array}{l}\text { Neutrophil } \\
\text { Eosinophil } \\
\text { Macrophage } \\
\text { Basophil } \\
\text { T lymphocyte } \\
\text { Endothelial cell } \\
\text { Keratinocyte }\end{array}$ & $5 q$ & $\begin{array}{l}\text { Stimulates growth of neutrophilic, eosinophilic, monocytic, } \\
\text { erythrocytic and megakaryocytic precursor cells } \\
\text { Activates mature neutrophils, eosinophils and monocytes } \\
\text { Augments neutrophil- and eosinophil-mediated cytotoxicity against } \\
\text { microorganisms and/or tumour cells } \\
\text { May stimulate leukemic progenitor proliferation } \\
\text { Supports hematopoietic target cell survival }\end{array}$ & $\begin{array}{l}7-9,17 \\
20-27,31,33 \\
34\end{array}$ \\
\hline M-CSF & Macrophage & $5 q$ & $\begin{array}{l}\text { Supports monocyte proliferation, maturation and survival in vitro } \\
\text { Augments monocyte-mediated anti-tumour cytotoxicity } \\
\text { Supports target cell survival }\end{array}$ & 1,2 \\
\hline IL-1 & $\begin{array}{l}\text { Early } \\
\text { hematopoietic } \\
\text { progenitors also } \\
\text { responsible to } \\
\text { other CSFs }\end{array}$ & $2 q$ & $\begin{array}{l}\text { Sensitizes early progenitors to effects of other CSFs } \\
\text { Induces CSF release by accessory cells } \\
\text { Improves survival during lethal Gram-negative infection in mice }\end{array}$ & $22,46,47$ \\
\hline $\begin{array}{l}\text { Erythro- } \\
\text { poietin }\end{array}$ & $\begin{array}{l}\text { Erythroid precursor } \\
\text { cells }\end{array}$ & $7 q$ & $\begin{array}{l}\text { Induces hemoglobin formation } \\
\text { Stimulates committed erythroid progenitor proliferation }\end{array}$ & 13,14 \\
\hline
\end{tabular}

extramedullary sources. Some are produced from lymphocytes and are therefore true lymphokines or interleukins (eg, GM-CSF and multi-CSF or interleukin-3), while others are produced by fibroblasts and epithelial cells (G-CSF, M-CSF, GMCSF and interleukin-6) or liver cells (erythropoietin), to name a few $(11,12)$. It is also clear that some CSFs may also have nonhematopoietic targets, as illustrated by the interaction of GM-CSF with its receptor on keratinocytes and endothelial cells. Table 1 summarizes the distinguishing characteristics of six natural CSFs for which recombinant counterparts are now available.

\section{HUMAN CSFs}

To date, most human clinical trials of recombinant human CSFs have focused on their potential application to the treatment of congenital neutropenias, cancer and hematopoietic disorders. Recombinant erythropoietin has been shown to be effective in reducing anemia of renal insufficiency, and may become useful in cancer patients whose natural erythropoietin is reduced $(13,14)$. A gene regulating megakaryocytopoiesis has been identified, and a recombinant product will likely be available soon for testing. However, the four recombinant CSFs which will have the greatest impact on preventing neutropenia and infection when myelopoiesis is abnormal or disrupted are G-CSF, GM-CSF, interleukin-1 and interleukin-3 (M-CSF may have restricted usefulness for reducing specific infections or boosting anti-tumour responses, but only very preliminary clinical testing has occurred to date).

These CSFs are distinct in ways that may be conducive to sequential administration in the future. Interleukin-3 stimulates the clonal proliferation of very early, multipotent progenitors in normal bone marrow cell populations as well as in those previously treated with chemotherapy $(15,16)$. GM-CSF targets later progenitors for proliferation and promotes neutrophil and macrophage differentiation and maturation (17). G-CSF acts exclusively on cells committed to the neutrophilic granulocytic lineage to promote neutrophil proliferation and terminal maturation (18). All three CSFs also enhance target cell survival by suppressing apoptosis, the normal physiological process by which cells actively self-destruct and die (19). Different sequential combinations of these CSFs have resulted in additive or synergistic increases in proliferative and maturational capabilities, suggesting future schedules which may allow for reduced side effects and cost of individual CSFs while maintaining optimal clinical efficacy. Table 2 lists the types of conditions for which these CSFs have been tested thus far. Recombi- 
TABLE 2

Clinical response to granulocyte colony-stimulating factor (G-CSF) and granulocyte/macrophage colony-stimulating factor (GM-CSF) in humans

\begin{tabular}{|c|c|c|c|}
\hline Disease state & rhuCSFs & Results & References \\
\hline \multicolumn{4}{|l|}{ Congenital or acquired severe neutropenia } \\
\hline Kostmann's syndrome & G-CSF & $\begin{array}{l}\text { Improved absolute neutrophil count } \\
\text { Accelerated improvement in infection recovery }\end{array}$ & 58,59 \\
\hline Idiopathic & GM-CSF & Improvement in absolute neutrophil count & 61 \\
\hline Cyclic (collie dogs) & GM-CSF & No effect & 62 \\
\hline \multicolumn{4}{|l|}{ Disease-induced neutropenia } \\
\hline Hairy cell leukemia & G-CSF & Improvement in disease- and treatment-induced neutropenia & 66 \\
\hline Acquired immune deficiency syndrome & GM-CSF & Improvement in disease-induced neutropenia & 67 \\
\hline Myelodysplastic syndromes & G-CSF & $\begin{array}{l}\text { Enhancement of bone marrow myeloid maturation } \\
\text { Augmented neutrophil function }\end{array}$ & 63 \\
\hline \multicolumn{4}{|l|}{ Treatment-induced neutropenia } \\
\hline Previously treated cancer patients & G-CSF & $\begin{array}{l}\text { Dose-dependent rise in absolute neutrophil count } \\
\text { Preservation of neutrophil function }\end{array}$ & 68 \\
\hline \multirow[t]{2}{*}{ Cancer patients receiving chemotherapy } & G-CSF & $\begin{array}{l}\text { Improved absolute neutrophil count nadir; reduced febrile } \\
\text { neutropenia, antibiotic requirements and hospitalization } \\
\text { Reduced incidence mucositis }\end{array}$ & $71-73$ \\
\hline & GM-CSF & $\begin{array}{l}\text { Improved absolute neutrophil count nadir; reduced febrile } \\
\text { neutropenia, reduced neutropenic days and fewer infectious } \\
\text { complications }\end{array}$ & $77-79$ \\
\hline \multirow[t]{2}{*}{ Autologous bone marrow transplantation } & G-CSF & $\begin{array}{l}\text { Fewer febrile days, fewer neutropenic days, fewer days on } \\
\text { antibiotics and fewer infections }\end{array}$ & 74.75 \\
\hline & GM-CSF & $\begin{array}{l}\text { As with G-CSF but also more rapid platelet recovery } \\
\text { Improved graft survival }\end{array}$ & $80-83$ \\
\hline
\end{tabular}

ThuCSFs Recombinant human colony-stimulating factors

nant human GM-CSF and recombinant human G-CSF have been the most extensively studied CSFs and their application to reducing the risk of infection in various clinical situations will be discussed in detail. Clinical trials using interleukin- 1 have not been completed, but the promise of this agent in the control or eradication of infection as illustrated in animals will be highlighted. The potential role of other CSFs or interleukins through their interactions with recombinant human GM-CSF and recombinant human G-CSF will also be reviewed (eg, interleukin-1). Early clinical trials of recombinant human interleukin-3 have just begun and data regarding its effect on clinical outcomes such as infection are not yet available.

\section{DIFFERENTIAL EFFECTS OF G-CSF AND GM-CSF ON NEUTROPHIL FUNCTION}

Both recombinant human G-CSF and recombinant human GM-CSF augment most aspects of neutrophil function. While neither agent can trig- ger a respiratory burst in neutrophils under conventional assay conditions, they do prime neutrophils to generate an enhanced burst in response to formylated peptides such as $n$-formylmethionylleucylphenylalanine (FMLP) $(20,21)$. Since they do not prime or trigger the respiratory burst of monocytes and macrophages which can endogenously secrete both agents, it appears that macrophages could provoke bursts in neutrophils in vivo $(22,23)$. Whether or not these CSFs enhance the burst initiated by contact with infecting organisms is not yet known. Other common effects on neutrophils include the modulation of FMLP and immunoglobulin A receptors, an increase in the adhesion properties of neutrophils, enhancement of phagocytosis, and an augmentation of neutrophil-mediated cytotoxic activity against some tumour cell lines and cells infected with human immunodeficiency virus (24-27). While recombinant human G-CSF is a chemotactic signal for neutrophils, the data on recombinant human GMCSF is conflicting, with one assay showing migration inhibition and the other showing chemotaxis (28). One study also reported the inhibition of 
neutrophil migration during continuous intravenous infusion of recombinant human GM-CSF after autologous bone marrow transplantation (29). Recombinant human G-CSF stimulates the secretion of alpha-interferon from mature neutrophils. Since the latter is a suppressant of neutropoiesis, it may play a role in mediating negative feedback following neutrophil stimulation by recombinant human G-CSF (30). Besides restoring the defect in superoxide release of neutrophils inherent in myelodysplastic syndromes, recombinant human G-CSF can enhance the FMLPstimulated superoxide release of neutrophils generated in vivo during recovery after cytotoxic chemotherapy. Similarly, recombinant human GM-CSF can enhance superoxide production in patients with refractory cancer (31). Thus, these CSFs appear qualitatively and quantitatively to support neutrophil recovery after myelosuppressive therapy.

Eosinophils are also stimulated by recombinant human GM-CSF, the effect of which may exceed that seen for granulocyte neutrophils. Functional augmentation occurs for superoxide production, protein synthesis, antibody-dependent cytotoxicity against tumour cells, and adherence to and killing of Schistosoma mansoni $(32,33)$. These effects could be exploited to boost host defences against this and other parasitic diseases.

\section{STUDIES IN ANIMALS}

Recombinant human G-CSF: Several murine models have been established for the study of $\mathrm{G}$-CSF. In response to early concerns that exogenously administered CSFs could lead to leukemic transformation or the development of myelodysplastic disorders, Chang et al (34) transplanted murine bone marrow cells, which were transfected with a G-CSF cDNA-bearing retroviral vector, into lethally irradiated donors. These mice produced very high levels of G-CSF, with marked neutrophilic granulocytosis in hematopoietic tissues and granulocytic infiltration of the liver and lung. However, no tumours occurred despite chronic G-CSF secretion, suggesting that chronic G-CSF administration does not lead to neoplastic transformation of normal hematopoietic cells. Cheers et al (35) studied two strains of mice infected with Listeria monocytogenes, one genetically resistant (C57 $\mathrm{BL} / 10$ ) and one susceptible (BALB/cJ) to $L$ monocytogenes infection. They correlated the release of serum CSFs with the cause of infection and the colony-forming cell response in the bone marrow to infection (previous studies suggested that higher colony-forming cell levels in the marrow predicted for better survival from listeria infection). As predicted, colony-forming cell levels were lower in the sensitive strain, but serum M-CSF and G-CSF levels were higher in this strain. This suggested a genetically determined resistance of colony-forming cells to respond to elevated levels of these CSFs and thus may contribute to the inherent sensitivity of this strain to listeria infection.

Matsumoto et al (36) infected mice intraperitoneally with Pseudomonas aeruginosa, Serratia marcescens, Escherichia coli, Staphylococcus aureus or Candida albicans four days after receiving $200 \mathrm{mg} / \mathrm{kg}$ of cyclophosphamide intraperitoneally. This routinely resulted in severe neutropenia and death from infection within four days. When human G-CSF was administered as a daily subcutaneous injection for four days beginning the day after infection, mice were protected against neutropenia and infection in a dose-dependent manner. At the 1.0 or $2.5 \mu \mathrm{g}$ doses, complete protection from infection was achieved for all species except $E$ coli. These clinical findings were associated with the generation of highly active oxygen radicals in peritoneal exudate cells compared to controls. The human G-CSF itself did not inhibit bacterial growth in vitro. Recently, Welte et al (37) developed a primate model of cyclophosphamide-induced neutropenia. As in the murine model, recombinant human G-CSF prevented the development of severe and prolonged neutropenia compared to controls.

In a recent study by Fushiki et al (38), recombinant human G-CSF protected mice against whole body irradiation-induced neutropenia after they received 0.5 or 1.0 Gray by a single dose, or 0.5 Gray for five consecutive days. Neutrophil nadirs were improved and neutrophil recovery was facilitated. Collectively, these data suggested that: clinical states may exist in which inherent resistance to G-CSF results in an increased susceptibility to infection; chronic administration of recombinant human G-CSF is not associated with malignant transformation; and recombinant human G-CSF may be useful in overcoming chemotherapy- or radiotherapy-induced neutropenia, and may result in increased protection against common pathogens. The myeloprotective effects may be synergistically augmented when interleukin-1 is given with G-CSF. Interleukin-1 induces endogenous CSFs, may sensitize progenitors to stimulation by G-CSF, and protects progenitors from the effects of radiation (3).

Recombinant human GM-CSF: Chronic recombinant human GM-CSF stimulation in a transgenic mouse model resulted in multiorgan infiltration of not only neutrophils but also eosinophils and macrophages $(39,40)$. Chronic activation of these inflammatory cells was more devastating than the increased hemopoietic production, resulting in 
retinal blindness and a wasting syndrome which reduced survival. Donahue et al (41) and Mayers et al (42) showed that by continuous intravenous infusion or subcutaneous injection, recombinant human GM-CSF produced marked (three- to sixfold) increases in circulating granulocytes, eosinophils, monocytes and lymphocytes, but not in platelets or erythrocytes in primates. Neutrophil function was also enhanced. In autologous bone marrow transplantation models of mice and primates, recombinant human GM-CSF significantly shortened the period of neutropenia and thrombocytopenia compared to controls $(43,44)$. These studies led quickly to human trials of recombinant human G-CSF and recombinant human GM-CSF in various immunocompromised states.

Recombinant human interleukin-1: Recombinant human interleukin-1 has been primarily investigated in combination with other CSFs. This is due to its ability to induce the release of other CSFs (such as G-CSF) by other cells and to sensitize cells to the effects of other CSFs. However, recent data suggest a potential role for interleukin- 1 in favorably altering the outcome of established infections. Encouraged by reports of a protective effect in non-neutropenic mice infected with Ps aeruginosa or Klebsiella pneumoniae, van der Meer et al (45) infected mice suffering from cyclophosphamideinduced neutropenia with $P$ s aeruginosa by intramuscular injection.

Mice receiving recombinant human interleukin- 1 as a single intraperitoneal injection $24 \mathrm{~h}$ before infection were compared with mice which did not receive recombinant human interleukin-1. Animals receiving recombinant human interleukin-1 benefited whether or not they also received gentamicin. Survival was significantly improved (98\% versus $71 \%$ at $24 \mathrm{~h}$; and $61 \%$ versus $11 \%$ at $48 \mathrm{~h} ; \mathrm{P}<0.001)$ despite no difference in peritoneal macrophage function or the number of bacteria cultured from various organs. While the reason for this striking result is not clear, further study is warranted to understand the potential role of interleukin- 1 in anti-infection therapy. In a more recent study, the same group reported that recombinant human interleukin-1 given as a single low dose accelerated neutrophil recovery following cyclophosphamide-induced neutropenia (46). The mechanism of this observation may be the endogenous release of G-CSF and/or GM-CSF by interleukin- 1 targets such as endothelial cells or bone marrow stromal cells (3). These studies suggest a future role for interleukin-1 as an adjunct to antibiotics in the treatment and prevention of infections in immunocompromised and noncompromised patients.

\section{HUMAN CLINICAL TRIALS}

Treatment schedules and toxicity: Recombinant human G-CSF was originally cloned and expressed through an $E$ coli vector in 1985. The biochemical aspects of this agent are reviewed elsewhere (18), and no significant biological difference has been detected compared to the natural product. No significant toxicity has been reported at maximally therapeutic doses. Bone pain is relatively frequent, and prevented or treated with acetaminophen. Low grade fevers, flu-like symptoms, blood pressure changes and liver function test abnormalities have been reported but are infrequent at most doses (less than $40 \mu \mathrm{g} / \mathrm{kg}$ ) (47). The neutrophil response is dose-dependent, and subcutaneous bolus, continuous subcutaneous infusion and intravenous infusion appear to be equally effective (48).

Initial phase I testing of recombinant human GM-CSF showed a dose-response for circulating neutrophils at doses ranging from 0.3 to $60 \mu \mathrm{g} / \mathrm{kg}$. All routes of administration tested were effective (intravenous 30 mins to continuous infusion, subcutaneous bolus, or subcutaneous continuous infusion) except the intravenous bolus route (49). However, dose-limiting toxicity occurred at dosages above $20 \mu \mathrm{g} / \mathrm{kg}$ as hypotension, severe myalgias, pulmonary toxicity or pericarditis (50). Long term, low dosages $(0.25$ to $4 \mu \mathrm{g} / \mathrm{kg})$ as a daily subcutaneous bolus for up to six months, resulted in sustained efficacy and mild, mainly cutaneous, toxicity (51). Pharmacokinetic data suggested that a daily subcutaneous injection of $10 \mu \mathrm{g} / \mathrm{kg}$ gave adequate daily serum levels of greater than 1 $\mathrm{ng} / \mathrm{mL}$ for more than $12 \mathrm{~h}$ (52). In a study comparing intravenous and subcutaneous dosing, Lieschke et al (49) recommended that dosages from 3 to $15 \mu \mathrm{g} / \mathrm{kg} /$ day given intravenously or subcutaneously be used in phase II trials. The subcutaneous route was preferable because of a lower incidence of generalized rash, fever and 'first dose reactions'. Such reactions included flushing, tachycardia, hypotension, muscle and bone pain, dyspnea, nausea and vomiting, and/or syncope, and can occur at first injection but not subsequent injections of the same chemotherapy cycle. These reactions have been more frequent in patients with small cell lung cancer (53).

Toxicity of recombinant human GM-CSF is generally greater than that with recombinant human G-CSF at recommended doses. Generalized rash is infrequent, but local rashes at the injection site occur in $40 \%$ of patients receiving subcutaneous injection (54). Other common side effects include low grade fever, bone pain and lethargy; the latter can be profound. While prophylactic acetaminophen and antihistamine usually control or prevent 
most of these effects, the author has found that a nonsteroidal anti-inflammatory drug (NSAID) at low doses may be required to control severe bone pain, fatigue and fever $(55,56)$.

The lineage-specific nature of these agents and their ability to promote both proliferation and functional maturation of neutrophil progenitors has led to clinical trials involving a diversity of disease states: cyclic and congenital neutropenia; myelodysplastic syndromes; disease-induced neutropenia (hairy-cell leukemia); and therapyinduced neutropenia (chemotherapy and bone marrow transplantation).

Congenital, idiopathic and cyclic neutropenia: Severe congenital neutropenia (Kostmann's syndrome) is characterized by severe neutropenia due to maturation arrest at the promyelocytic level. Absolute neutrophil counts are less than $0.2 \times 10^{9} / \mathrm{L}$, and patients experience frequent episodes of fever and systemic infection, often resulting in death despite antibiotics during infancy. Welte et al (57) treated five patients with Kostmann's syndrome with daily recombinant human G-CSF or GM-CSF (intravenous). In only one patient treated with GM-CSF did a significant increase in neutrophils occur; the other four patients responded with marked eosinophilia. By contrast, when treated with recombinant human G-CSF, all five patients had an increase in neutrophil counts above $1000 / \mathrm{mL}$. One patient showed resolution of an antibiotic-resistant pulmonary infiltrate caused by peptostreptococcus. Since Welte et al have shown normal or elevated G-CSF levels in these patients, it is likely that late neutrophil precursors have a defective response to physiological levels of G-CSF. Bonilla et al (58) have reported similar results in severe congenital neutrophilia patients also treated with recombinant human G-CSF. Since chronic G-CSF administration has not been linked to the appearance of normal cell transformation or clinical tumours, these patients may be treatable with regular dosing of this agent.

Vadhan-Raj et al (59) recently reported a clinical response to recombinant human GM-CSF in a patient with severe congenital neutrophilia with healing of chronic infected and inflammatory sites. They speculated that the resulting eosinophilic (but not neutrophilic) granulocytosis may have mediated this response. The authors also reported that patients with idiopathic neutropenia responded dramatically to GM-CSF, suggesting a different defect of CSF responsiveness in this disease. Ganser et al (60) reported a good response with normal healing in a patient with severe congenital neutrophilia after either continuous or bolus subcutaneous recombinant human GM-CSF.
This group also reported therapeutic improvement in the absolute neutrophil count of patients with chronic severe neutropenia of varying causes, including previous anticancer therapy, autoimmune disease and idiopathic severe neutropenia.

Cyclic neutropenia presents as regular oscillations of the number of neutrophils in the peripheral blood. Other blood cells are affected to a lesser degree. The periodicity of neutropenia is 20 to 24 days in humans and 12 to 14 days in dogs. Lathrop et al (61) treated grey collie dogs with recombinant human G-CSF or recombinant human GM-CSF. While recombinant human G-CSF eliminated the cyclic neutropenia and maintained a persistent neutrophilia, recombinant human GM-CSF had no effect. However, cyclic neutropenia recurred over time despite continued administration; this correlated with neutralizing antibodies in the blood and is not likely to occur in humans given this preparation.

Therefore, it appears that in a small group of patients with neutrophil dysmyelopoiesis, recombinant human G-CSF will likely become the standard treatment to prevent life threatening infections due to protracted neutropenia. However, some patients may require a trial of both agents if the underlying etiology is uncertain.

Myelodysplastic syndromes: Both recombinant human G-CSF and GM-CSF enhance the differentiation of leukemic and myelodysplastic myeloid cells. Therefore, caution must be taken when myelodysplastic patients are treated. Early studies, however, have demonstrated improved peripheral blood neutrophil counts in patients with myelodysplastic syndrome receiving recombinant human G-CSF. Negrin et al (62) showed that neutrophil function was preserved, bone marrow myeloid maturation enhanced, and erythrocyte transfusion frequency reduced. No conversion to leukemia occurred over a short follow-up period. Only 12 patients were treated and, as with other similar studies to date, no clinical data on reduction of febrile episodes or documented infection were reported.

Two recent trials used recombinant human GM-CSF by different routes in myelodysplastic syndrome patients. Thompson et al (63) treated 16 patients by daily subcutaneous bolus injection. Eleven of 13 patients receiving greater than or equal to $1.0 \mu \mathrm{g} / \mathrm{kg} /$ day had dose-related increases of two- to 194-fold of circulating neutrophils. However, in all but two patients, the counts fell to baseline after discontinuation of recombinant human GM-CSF. Chronic administration at $3 \mu \mathrm{g} /$ $\mathrm{kg} /$ day for up to nine weeks did not sustain the increase in four of five patients. Vadhan-Raj et al (64) reported similar results when giving recombi- 
nant human GM-CSF by continuous intravenous infusion for 28 days as two 14 day cycles with a two week rest interval. One patient in the first study progressed to acute leukemia after two doses of recombinant human GM-CSF. Interestingly, one patient in the second study died of sepsis despite recombinant human GM-CSF treatment, and the post mortem examination revealed multiorgan infiltration with immature myeloid cells, suggesting granulocytic sarcoma similar to findings in the murine models receiving chronic recombinant human GM-CSF. Elevations of platelet counts occurred in several patients in each study.

At this time, the limited success of chronic administration to maintain normal myelopoiesis in most patients and the concern about conversion to acute leukemia makes the future role of the CSFs in myelodysplastic syndrome uncertain. One report, however, suggested that recombinant human GM-CSF may have suppressed the abnormal clone as a mechanism of restoring normal hematopoiesis in a patient with a myelodysplastic syndrome (65).

Disease-induced neutropenia: Chronic lymphoid malignancies characterized by frequent infections include chronic lymphocytic leukemia and hairy cell leukemia. In the latter, neutropenia can occur as a consequence of disease or treatment. Alphainterferon and pentostatin are now standard treatments for this disease, and induce substantial improvements in neutrophil counts in 90\% of patients. However, two to six months of treatment may be required to achieve this; furthermore, a reduction in neutrophil counts may occur during the first month of therapy with alpha-interferon. Glaspy et al (66) recently treated four patients with hairy cell leukemia who had severe neutropenia. Each patient received increasing doses of recombinant human G-CSF for five to six weeks by daily subcutaneous injection. All three evaluable patients responded with increases in neutrophil counts from $0.9 \times 10^{9} / \mathrm{L}$ to greater than $4.0 \times 10^{9} / \mathrm{L}$ within the first two weeks; two patients experienced resolution of ongoing infection including periorbital skin infection in one patient and a perirectal abscess with sepsis despite broad spectrum antibiotics in the second patient. One patient developed neutrophilic dermatosis (Sweet's disease), which may be a rare dose-limiting side effect of recombinant human G-CSF. This report suggests that recombinant human G-CSF may be a useful adjunct to standard therapy for this disease by reducing the risk of life threatening infection before therapeutic response.

Patients with the acquired immune deficiency syndrome (AIDS) have numerous abnormalities of their host defences, not the least of which is leukopenia. This may be due to the disease itself or to drugs used in its treatment (eg, azidothymidine). Groopman et al (67) treated 16 patients with AIDS with good performance status and leukopenia. Circulating neutrophils and monocytes were dramatically increased after 14 days of low dose daily continuous intravenous infusion of recombinant human GM-CSF. The increase was gradual and sustained over the treatment period. No life threatening toxicity occurred, and only a few patients had mild symptoms controlled with symptomatic measures. Thus, recombinant human GM-CSF may become a useful adjunct to the treatment of patients with AIDS. Trials of subcutaneous dosing, however, are needed to allow practical outpatient therapy. In addition, these patients may benefit from the previously mentioned augmenting effects of recombinant human GM-CSF on neutrophil toxicity against human immunodeficiency virus (HIV) infected cells (27).

Treatment-induced neutropenia with recombinant human G-CSF: A growing number of therapeutic interventions are subjecting an increasing number of cancer patients to life threatening infections. These interventions generally involve the intensification of chemotherapy delivery by administration of drugs at higher doses, at more frequent intervals, or both. The impetus for developing these strategies has been provided by the advent of autologous bone marrow transplantation techniques and the growing acceptance that increasing the doses of established agents will yield higher response rates. Whether this increased risk of morbidity or mortality to the patient will result in significant improvements in survival, however, is yet to be determined.

The number of clinical trials in this area has grown rapidly in the last two to three years. While most trials have focused on the optimal dose and schedule which will prevent therapy-induced neutropenia, relatively few have tried to demonstrate conclusive improvements in clinical parameters such as reduction in febrile neutropenic episodes and infection rates and, in the case of autologous bone marrow transplantation, reduced hospital stays. In addition, most studies remain ongoing and have only been reported in abstract form. This review will examine conclusions reached by published and completed studies.

The earliest phase I toxicity trials showed that cancer patients tolerated recombinant human GCSF very well (68). Furthermore, recombinant human G-CSF increased peripheral neutrophil counts in a dose-dependent fashion even in patients with previous chemotherapy, and neutrophil function was normal by in vitro testing. 
Platelet counts, on the other hand, were unchanged or fell during recombinant human G-CSF therapy. Side effects were generally restricted to bone pain rarely requiring analgesia, and no augmentation of tumour growth has been reported in vivo. However, reports of in vitro enhancement of nonhematopoietic tumours by recombinant human GM-CSF has stimulated continued monitoring of tumour responses in clinical trials $(69,70)$.

With such an impressive therapeutic index, some studies have examined the optimal dose and schedule to reduce or abrogate chemotherapy-induced neutropenia. Morstyn et al (48) studied patients with extensive cancer, nearly two-thirds of whom received prior chemotherapy. All patients received melphalan $25 \mathrm{mg} / \mathrm{m}^{2}$ intravenously, and recombinant human G-CSF was given subcutaneously by bolus or continuous infusion in a wide variety of schedules, one of which included prechemotherapy recombinant human G-CSF. Dosedependent protection against severe neutropenia occurred; the absolute neutrophil count fell to less than $1.0 \times 10^{9} / \mathrm{L}$ in six of 12 patients receiving 3 $\mu \mathrm{g} / \mathrm{kg}$ or less of recombinant human G-CSF, whereas this occurred in only three of 19 receiving doses in excess of $10 \mu \mathrm{g} / \mathrm{kg}$. The authors concluded that $10 \mu \mathrm{g} / \mathrm{kg} /$ day by subcutaneous infusion provided the most reliable protection against neutropenia in this regimen.

Several studies have now been published reporting the effects of recombinant human G-CSF on clinical outcomes. Gabrilove et al (71) treated patients at various stages of transitional cell carcinoma of the urothelium with methotrexate, vinblastine, doxorubicin and cisplatin. The doses used are routinely highly myelotoxic; patients received recombinant human G-CSF by short intravenous infusion for six daily doses one week prior to chemotherapy, and another eight day course from days 4 to 11 after chemotherapy was begun. Cohorts of three to five patients received varying dosages of recombinant human G-CSF from 1 to $60 \mu \mathrm{g} / \mathrm{kg} /$ day. Recombinant human G-CSF was given to 18 patients in cycle 1 and withheld during cycle 2 . Six patients received no recombinant human G-CSF during cycle 1 and served as controls. A dose-dependent increase in neutrophil counts was evident in all patients during recombinant human G-CSF treatment. There were $92 \%$ fewer days in which the absolute neutrophil count was less than $0.5 \times 10^{9} / \mathrm{L}$. A febrile neutropenic episode (ie, absolute neutrophil count less than $1.0 \times 10^{9} / \mathrm{L}$ ) occurred in four of the 24 cycles ( $17 \%$ ) without recombinant human G-CSF, and in only one of 18 cycles $(6 \%)$ where recombinant human $\mathrm{G}-\mathrm{CSF}$ was given. Antibiotics were required for four to 15 days in the first group, and for only one day in patients receiving recombinant human G$\mathrm{CSF}$. Again, the main side effect of recombinant human G-CSF was mild to moderate bone pain in $72 \%$ of patients. Interestingly, less chemotherapyinduced mucositis was noted in the cycles receiving recombinant human G-CSF. This study showed, therefore, that recombinant human G$\mathrm{CSF}$ can reduce both the risk of infection as measured by days of neutropenia at less than $0.5 \times 10^{9} / \mathrm{L}$, and the frequency of febrile neutropenic episodes in patients receiving routinely myelotoxic combination chemotherapy.

Bronchud et al $(48,72)$ has reported on several phase I/II studies of patients receiving intensive chemotherapy for small cell lung cancer, breast cancer and ovarian cancer. In the first study, patients with small cell lung cancer received ifosphamide, mesna, doxorubicin and etoposide every three weeks for six cycles. At entry into the trial, sequential pairs of patients received 1 to 40 $\mu \mathrm{g} / \mathrm{kg} /$ day of recombinant human G-CSF by continuous intravenous infusion daily for 14 days, beginning $24 \mathrm{~h}$ after completion of chemotherapy. Patients were assigned to receive recombinant human G-CSF sequentially on odd or even cycles. Nine of 12 patients completed two cycles; in the six evaluable patients, there was a significant improvement in absolute neutrophil count on day 15 for cycles with recombinant human G-CSF compared to those without. The most striking difference occurred in the 5 to $40 \mu \mathrm{g} / \mathrm{kg}$ range. More importantly, six patients experienced episodes of febrile neutropenia requiring hospitalization and intravenous antibiotics during cycles without recombinant human G-CSF, whereas no such episodes occurred during cycles with recombinant human $\mathrm{G}-\mathrm{CSF}(\mathrm{P}=0.012)$. No clinical toxicity was seen, and neutrophil mobility and bactericidal activity were normal before and after the nadir. Therefore, it appeared that recombinant human G-CSF administration resulted in less febrile neutropenia, hospitalization and antibiotic therapy.

In their second study, Bronchud et al (72) used a fixed dosage schedule of continuous intravenous recombinant human G-CSF $(10 \mu \mathrm{g} / \mathrm{kg} /$ day, days 2 to 8 ; and $5 \mu \mathrm{g} / \mathrm{kg} /$ day, days 9 to 12 ), and escalated the dose of doxorubicin given every three weeks to successive patient cohorts with advanced breast or ovarian cancer. A 2.2- to 4.5fold increase in the dosage intensity (in $\mathrm{mg} / \mathrm{m}^{2}$ /week) of doxorubicin could be given with recombinant human G-CSF, compared to the historical experience without it. A controlled trial using very dose-intensive chemotherapy without autologous bone marrow transplantation for a variety of advanced cancers has been reported 
recently by Neidhart et al (73). All patients received etoposide and cyclophosphamide at about five times the doses given in standard treatment protocols, and cisplatin at about twice the standard dose. Therapy was given every five weeks for up to four cycles. Doses were not changed for the subsequent cycle unless either the absolute neutrophil count was less than $0.1 \times 10^{9} / \mathrm{L}$ for more than 14 days or the platelet count fell below $10 \times 10^{9} / \mathrm{L}$.

The study compared patients receiving escalating dosages of recombinant human G-CSF (at 20, 40 and $60 \mu \mathrm{g} / \mathrm{kg} /$ day) $(\mathrm{n}=10)$ to those receiving no recombinant human G-CSF in cycle 1 as a control group $(n=11)$ and eight patients who received recombinant human G-CSF only after cycle 1 . Recombinant human G-CSF was given as a 30 min daily intravenous infusion for 21 days beginning three days after chemotherapy or until the absolute neutrophil count rose above $15.0 \times 10^{9} / \mathrm{L}$ for five days. The results revealed that, compared to controls, patients receiving recombinant human G-CSF had a significantly shorter median duration of severe granulocytopenia (less than $\left.0.1 \times 10^{9} / \mathrm{L}\right)(\mathrm{P}<0.03)$. At the higher dosages, the time to recovery of the absolute neutrophil count above $0.5 \times 10^{9} / \mathrm{L}$ was significantly shorter (six versus 12 days, $\mathrm{P}<0.02$ ), and patients required less antibiotic therapy and less hospitalization compared to the lowest dose or controls. Seven of eight patients who received recombinant human G-CSF after cycle 1 had a shorter period of neutropenia on recombinant human G-CSF compared to cycle 1 . The only toxicity related to recombinant human $\mathrm{G}$-CSF was bone marrow pain requiring morphine in two patients.

Taylor et al (74) used a similarly intensive chemotherapy regimen (high dose carmustine, cyclophosphamide and etoposide) but with autologous bone marrow transplantation support in 18 patients with relapsed Hodgkin's disease. Recombinant human G-CSF was given as in the Neidhart et al study (71) using their highest dosage $(60$ $\mu \mathrm{g} / \mathrm{kg}$ ) but for a maximum of 28 instead of 21 days beginning on the day of transplantation. This group was compared with a cohort of 58 historical controls treated with the same regimen minus recombinant human G-CSF. Results showed that absolute neutrophil count recovery to $0.1 \times 10^{9} / \mathrm{L}$, $0.5 \times 10^{9} / \mathrm{L}$, and $1.0 \times 10^{9} / \mathrm{L}$ were all highly significantly more rapid using recombinant human GCSF (ie, median 13 versus 22 days to reach $\left.0.5 \times 10^{9} / \mathrm{L}\right)$. Infectious complications were markedly reduced as well. Parameters included fewer febrile days (median three versus seven in controls) and fewer bacteremic episodes (17 versus $36 \%$ ). These data are similar to those reported by
Sheridan et al (75) in a trial where 15 patients with solid tumours or acute lymphoblastic leukemia were treated with high dose chemotherapy and autologous bone marrow transplantation. Compared to 18 matched controls, recombinant human G-CSF given at $20 \mu \mathrm{g} / \mathrm{kg}$ as a daily continuous subcutaneous infusion resulted in significant acceleration in neutrophil recovery, fewer days on intravenous antibiotics, and less time in reverse isolation. From these data one can conclude that: recombinant human G-CSF can be reliably and safely administered by continuous or short infusion intravenous or subcutaneous routes; a dose-response effect occurs at up to 60 $\mu \mathrm{g} / \mathrm{kg}$ or higher with a minimal increase in toxicity; more intensive chemotherapy regimens may require higher doses of recombinant human $\mathrm{G}^{-}$ CSF for maximal myeloprotection; and clinical outcomes of infection (including reduced severity and duration of neutropenia, fewer severe infections, and fewer days of antibiotics and hospitalization) are improved using recombinant human G-CSF during high dose chemotherapy and in at least some disease states in which chronic severe neutropenia exists.

Treatment-induced neutropenia with recombinant human GM-CSF: The use of CSFs to prevent treatment-induced myelosuppression requires appropriate timing in order to optimize protection. Talmadge et al (76) found that mice given lethal doses of irradiation required CSF immediately after, whereas those receiving alkylating agents were best protected when CSF was begun $48 \mathrm{~h}$ after drug administration. This observation suggests that time must pass to allow for the clearance of the effects of alkylating agents from the bone marrow, to prevent greater early progenitor depletion by the cytotoxic effects of lingering alkylating drug during recombinant human GM-CSF stimulation. The duration of therapy is also important: cycles of chemotherapy should be as short as possible, and recombinant human GM-CSF should be stopped prior to the next cycle dose to reduce stimulation of precursors before exposure to chemotherapy. Morstyn et al (77) found that seven days of daily subcutaneous recombinant human GM-CSF beginning $24 \mathrm{~h}$ after completion of chemotherapy were sufficient to prevent major neutropenia in patients receiving etoposide and carboplatin every three to four weeks.

While numerous preliminary reports have been published in abstract form on the effects of recombinant human GM-CSF on chemotherapy-induced myelosuppression, only a few have been fully published in peer review journals. Antman et al (78) reported that recombinant human GM-CSF given by continuous intravenous infusion during 
cycle 1 for patients receiving highly myelosuppressive therapy for sarcomas significantly reduced the severity and duration of neutropenia compared to cycle 2, where recombinant human GMCSF was not given. Twelve patients completed both cycles of chemotherapy. Interestingly, platelet nadirs were also markedly improved. No doseresponse correlation occurred over dosages of 4 to $64 \mu \mathrm{g} / \mathrm{kg}$, and dose-limiting toxicity occurred above $32 \mu \mathrm{g} / \mathrm{kg}$. The duration of neutropenia was reduced from a mean of 7.4 (cycle 2) to 3.5 days (cycle 1). There were seven hospital admissions for febrile neutropenia during each cycle, with one culture-documented septic episode in cycle 2.

More recently, Gianni et al (79) treated 15 patients with breast cancer and lymphoma with cyclophosphamide $7 \mathrm{~g} / \mathrm{m}^{2}$ and recombinant human GM-CSF $5.5 \mu \mathrm{g} / \mathrm{kg}$ by daily continuous intravenous infusion for seven to 14 days beginning at one or five days after chemotherapy. A nonrandomized control group received the same chemotherapy without recombinant human GM-CSF. The median recovery of the absolute neutrophil count to more than $1.0 \times 10^{9} / \mathrm{L}$ for patients receiving recombinant human GM-CSF was reduced from 20 to 14 days, and patients on recombinant human GM-CSF experienced fewer infectious complications (7 versus 24\%). (Platelet transfusions were also reduced due to more rapid platelet recovery.) The authors emphasized an important clinical problem: distinguishing fever due to recombinant human GM-CSF from that due to infection. They emphasized the absence of systemic symptoms and the rapid disappearance of fever after stopping recombinant human GM-CSF as distinguishing features. However, the possibility of masking of an infection-related fever while using acetaminophen or an NSAID to control other symptoms remains. Indeed, $20 \%$ of Gianni's patients had myalgias and bone pain; $40 \%$ had skin rash; and $40 \%$ had fever over $38.2^{\circ} \mathrm{C}$.

Recombinant human GM-CSF has improved the morbidity associated with therapy intensification using autologous bone marrow transplantation support in ways similar to that seen with recombinant human G-CSF. Brandt et al (80) demonstrated earlier dose-dependent increases in neutrophils and total white blood cell counts (by day 14 post transplant) and reduction in number of neutropenia days from 17 to 12 , all compared to historical controls. Nadler and Rabinowe are conducting a randomized trial of patients with relapsed non-Hodgkin's lymphoma receiving high dose chemotherapy. In a preliminary report of the first 23 patients, they reported significantly fewer days to an absolute neutrophil count above $0.5 \times 10^{9} / \mathrm{L}$ (19 versus 23), a shorter duration of intravenous antibiotic support (10 versus 19 days), fewer hospitalized days (22 versus 26), and fewer platelet transfusions (81). An update of this study was recently published (82). Another patient group that may benefit from recombinant human GM-CSF is that with autologous or allogeneic bone marrow graft failure. Primary infection due to persistent neutropenia is a major reason for morbidity and mortality. Nemunaitis et al $(83,84)$ treated 37 patients in graft failure with recombinant human GM-CSF as a daily intravenous infusion for 14 to 21 days. Twenty-one patients responded, with the absolute neutrophil count exceeding $0.5 \times 10^{9} / \mathrm{L}$; only the neutrophil lineage responded. The survival of all patients was significantly better than a matched historical cohort with graft failure (at one year, 44 versus 23\%, $\mathrm{P}=0.003$ ).

One further application of CSFs is in the area of peripheral blood stem cell transplantation. Siena et al (85) have shown that the peripheral blood of cancer patients recovering from high dose cyclophosphamide therapy is enriched for $\mathrm{CD}^{+} 4^{+}$hematopoietic stem cells. This enrichment is markedly improved when intravenous recombinant human GM-CSF is given daily for 14 days after chemotherapy. The yield of stem cells was 10- to 20-fold higher than that achieved through conventional autologous bone marrow transplantation. This method provides much simpler stem cell reconstitution by eliminating general anesthesia and pain from multiple biopsies, and circumventing bone marrow which may have been previously irradiated. (Du et al [86] have reported that recombinant human G-CSF may also increase circulating early progenitor cells in the peripheral blood of cancer patients.)

More clinical trials are needed before the full clinical benefits of recombinant human G-CSF and recombinant human GM-CSF can be conclusively determined. To date, the most convincing studies are those which compare the clinical infection outcomes of patients who receive one cycle of treatment with a CSF and one without (intrapatient controls). However, this design is flawed by the fact that results of the second cycle may be affected by exposure of the bone marrow to chemotherapy during cycle 1 . Assigning patients to receive the CSF in cycle 1 or 2 by a randomization scheme reduces this problem but does not eliminate it. The best design would involve the random allocation of patients with the same disease receiving the same treatment to a CSF or "no CSF" arm (interpatient controls). Several such trials are in progress, such as that reported by Nadler et al (82), and a recently completed but not yet published study comparing the clinical infection out- 
TABLE 3

Potential therapeutic role of granulocyte colony-stimulating factor (G-CSF), granulocyte/macrophage colony-stimulating factor (GM-CSF) and interleukin-1 (IL-1) in humans

\begin{tabular}{lll}
\hline Factors & Diseases for which there is a potential therapeutic role & \\
\hline G-CSF & Congenital neutropenia & Idiopathic neutropenia \\
& ? Myelodysplastic syndromes & Acquired immune deficiency syndrome \\
& Hairy cell leukemia & Chronic lymphocytic leukemia \\
& Low grade lymphomas & Myelodysplasia \\
& Adjunct to autologous bone marrow transplantation & High dose chemotherapy \\
GM-CSF & Some congenital and idiopathic neutropenias & Adjunct to autologous bone marrow transplantation \\
& High dose chemotherapy & Parasitic infections \\
& Adjunct to stem cell reconstitution & ? Myelodysplastic syndromes \\
IL-1 & Adjunct to treatment of various disease states using other colony-stimulating factors \\
& Adjunct to antibiotic therapy in established infections & \\
\hline
\end{tabular}

comes of patients receiving recombinant human GM-CSF during therapy for small cell lung cancer. Patients were randomly assigned to receive either of two doses of recombinant human GM-CSF or no recombinant human GM-CSF during each cycle of chemotherapy. However, such trials require large numbers of patients to detect significant differences in clinical outcomes, and may be difficult to conduct in diseases such as chronic neutropenia.

\section{CANADIAN STUDIES OF RECOMBINANT HUMAN GM-CSF AND RECOMBINANT HUMAN G-CSF}

At present, clinical trials are being planned or have begun in the areas of bone marrow transplant support and chemotherapy dose intensification. Investigators in Vancouver are conducting trials of recombinant human GM-CSF and recombinant human interleukin-3 in patients undergoing autologous bone marrow transplantation. The National Cancer Institute of Canada's Clinical Trials Group has organized a Biologies Working Group through which several trials of recombinant human GM-CSF are being conducted. These are presently phase I trials assessing the safety of recombinant human GM-CSF and its effectiveness in protecting patients from myelosuppression while they receive higher than standard doses of chemotherapy. Priority has been set on trials in patients with ovarian cancer, small cell lung cancer, and lymphoma. Clinical outcomes being monitored include febrile neutropenia, intravenous antibiotic requirements and hospitalization. A trial of recombinant human interleukin-3 in patients with ovarian cancer is being planned. To date, no trials of recombinant human G-CSF have begun, but discussions with a major commercial producer of this agent have been indicated.

\section{FUTURE THERAPEUTIC APPLICATIONS}

The intensification of cancer therapy is expanding as a concept and as a basis for the design of a growing number of clinical trials. Along with this comes increased risk to the patient in an attempt to find more curative therapies. Reduction in infection risk will continue to be a major priority associated with these trials, and it is likely that recombinant human G-CSF, recombinant human GM-CSF and recombinant human interleukin-3 alone or in combination will become standard adjunctive therapies for an as yet unknown variety of intensive treatment regimens. Already these agents are the main therapeutic hope of patients suffering from congenital neutropenia, in whom morbidity and mortality from infection are a lifelong problem. An untouched but potentially productive area of application is the treatment of parasitic diseases. Recombinant human GM-CSF, in particular, has the potential not only to reduce treatment-induced neutropenia, but also to act as an immunostimulant to enhance eosinophilic responses and perhaps improve the response and survival of patients receiving antibiotic therapy. Finally, recombinant human interleukin-1 appears to have a broad spectrum of therapeutic value in conjunction with other CSFs, and perhaps on its own, as an adjunct to antibiotics in the treatment of serious Gram-negative infections. As a new modality of treatment, the CSFs and other cytokines are exciting additions to the established therapeutic armamentarium against infections and cancer (Table 3).

\section{REFERENCES}

1. Broxmeyer HE. Biomolecule-cell interactions and the regulation of myelopoiesis. Int $\mathrm{J}$ Cell Cloning 1986;4:378-405.

2. Moore MAS. The use of hematopoietic growth and differentiation factors for bone marrow stimulation. In: De Vita V, Rosenberg S, Helman SJ, eds. Important Advances in Oncology. Philadelphia: Lippincott, 1988:31-54.

3. Moore MAS, Warren DJ. Synergy of interleukin-1 and granulocyte colony-stimulating factor: In vivo stimulation of a stem-cell recovery and hematopoietic regeneration following 5-fluorouracil treatment of mice. Proc Natl Acad Sci USA 1987;84:7134-8. 
4. Dexter TM, Allen TD, Lajtha LG. Conditions controlling the proliferation of hematopoietic stem cells in vitro. J Cell Physiol 1977;91:335-44.

5. Messner HA. Human stem cells in culture. Clin Lab Haematol 1984; 13:393-404.

6. Sisson SD, Dinarello CA. Production of interleukin- $1 \alpha$, interleukin- $1 \beta$ and tumor necrosis factor by human mononuclear cells stimulated with granulocyte-macrophage colony-stimulating factor. Blood 1988:72:1368-74.

7. Reed SG, Nathan CF, Pihl DL, et al. Recombinant granulocyte-macrophage colony-stimulating factor activates macrophages to inhibit Trypanosoma cruzi and release hydrogen peroxide. J Exp Med 1987; 166:1734-46.

8. Handman E, Burgess AW. Stimulation by granulocyte-macrophage colony-stimulating factor of Leishmania tropica killing by macrophages. J Immunol 1979;122:1134-7.

9. Pettenati MJ, LeBeau MM, Lemons RS, et al. Assignment of CSF-1 to 5q33.1; evidence for clustering of genes regulating hematopoiesis and for their involvement in the deletion of the long arm of chromosome 5. Proc Natl Acad Sci USA 1987:84:2970-4.

10. Simmers RN, Webber LM, Shannon MF, et al. Localization of the G-CSF gene on chromosome 17 proximal to the break point in the $\mathrm{t}(15 ; 17)$ in acute promyelocytic leukemia. Blood 1987:70:330-2.

11. Sieff CA, Schickwann T, Faller DV. Interleukin-1 induces cultured endothelial cell production of granulocyte-macrophage colony-stimulating factor. $\mathrm{J}$ Clin Invest 1987;79:48-51

12. Fibbe WE, Damme J, Billiau A, et al. Interleukin-1 induces human marrow stromal cells in long term culture to produce G-CSF and M-CSF. Blood 1988;71:430-5.

13. Eschbach JW, Abdulhadi MH, Browne JK, et al. Recombinant human erythropoietin in anemic patients with end-stage renal disease. Ann Intern Med 1989;111:992-1000.

14. Oster W, Herrmann F, Gamm H, et al. Erythropoietin for the treatment of anemia of malignancy associated with neoplastic bone marrow infiltration. J Clin Oncol 1990;8:956-62.

15. Leary AG, Wank YC, Clark SC, et al. Recombinant gibbon interleukin-3 supports formation of human multilineage colonies and blast cell colonies in culture: Comparison with recombinant human granulocyte-macrophage colony-stimulating factor. Blood 1987;70:1343-8.

16. Gillio AP, Laver J, Abboud M, et al. IL-3 prevents neutropenia following 5-fluorouracil and cyclophosphamide-induced myelosuppression in cynomolgus monkeys. Blood 1988;72(Suppl 1): $117 \mathrm{a}$.

17. Clark SC. Biological activities of human granulocyte-macrophage colony-stimulating factor. Int J Cell Cloning 1988;6:365-77.

18. Souza LM, Boone TC, Gabrilove J, et al. Recombinant human granulocyte colonystimulating factor: Effects on normal and leukemic myeloid cells. Science 1986;232:61-5.

19. Williams GT, Smith CA, Spooncer E, Dexter TM, Taylor DR. Hematopoietic colony stimulating factors provoked cell survival by suppressing apoptosis. Nature 1990;343:76-9.
20. Weisbart RH, Golde DW, Clark SC, et al. Human granulocyte-macrophage colony-stimulating factor is a neutrophil activator. Nature 1985;314:361-3.

21. Wiesbart RH, Kwan L, Golde DW, Gasson JC. Human CSF-GM primes neutrophils for enhanced oxidative metabolism in response to the major physiologic chemoattractants. Blood 1987;69:18-21.

22. Broudy VC, Kaushansky K, Harlan JM, Adamson JW. Interleukin-1 stimulates human endothelial cells to produce granulocyte-macrophage colonystimulating factor and granulocyte colonystimulating factor. J Immunol 1987;139:464-8.

23. Piacibello W, Lu L, Wachter M, Rubin B, Broxmeyer HE. Release of granulocyte macrophage colony-stimulating factor from major histocompatibility complex class 2 antigen-positive monocytes is enhanced by a gamma interferon. Blood 1985;66:1343-51.

24. Fleischmann J, Golde DW, Weisbart RH, Gasson JC. Granulocyte-macrophage colony-stimulating factor enhances phagocytosis of bacteria by human neutrophils. Blood 1986;68:708-11.

25. Arnaout MA, Wang EA, Clark SC, Sieff CA. Human recombinant granulocyte-macrophage colony-stimulating factor increases cell-to-cell adhesion and surface expression of adhesion-provoking surface glycoproteins in mature granulocytes. J Clin Invest 1986:78:597-601.

26. Weisbart RH, Kacena A, Schuh A, Golde DW. CSF-GM induces human neutrophil IgA-mediated phagocytosis by an IgA Fc receptor activation mechanism. Nature 1988;332:647-8.

27. Baldwin GC, Fuller MD, Roberts RL, Ho DD, Golde DW. Granulocyte and granulocyte-macrophage colony stimulating factors enhance neutrophil cytotoxicity toward HIV infected cells. Blood 1989;74:1673-7.

28. Wang JM, Chen ZG, Colella S, et al. Chemotactic activity of recombinant human granulocyte colony-stimulating factor. Blood 1988;72:1456-60.

29. Peters WP, Stewart A, Affronti ML, Kim CS, Coleman RE. Neutrophil migration is defective during recombinant human granulocytemacrophage colony-stimulating factor infusion after autologous bone marrow transplantation in humans. Blood 1988;72:1310-5.

30. Shirafugi N, Matsuda S, Ogura H, et al. Granulocyte colony-stimulating factor stimulates human mature neutrophilic granulocytes to produce interferon $\alpha$. Blood 1990;75:17-9.

31. Caplain SS, Basford RE, Wing EJ, Shadduck RK. The effect of recombinant human granulocytemacrophage colony-stimulating factor on neutrophil activation in patients with refractory carcinoma. Blood 1989;73:636-8.

32. Owen WF, Rothenberg ME, Silberstein DS, et al. Regulation of human eosinophil viability, density, and function by granulocyte-macrophage colony-stimulating factor in the presence of 3T3 fibroblasts. J Exp Med 1987;166:129-41.

33. Silberstein DS, David JR. The regulation of human eosinophil function by cytokines. Immunol Today 1987:8:380-4.

34. Chang JM, Metcalf D, Gonda DJ, Johnson GR. Long-term exposure to retrovirally expressed granulocyte colony-stimulating factor induces a 
non-neoplastic granulocytic and progenitor cell hyperplasia without tissue damage in mice. Clin Invest 1989;84: 1488-96.

35. Cheers C, Haigh AM, Kelso A, et al. Production of colony-stimulating factors during infection: Separate determinations of macrophagegranulocyte-, granulocyte-macrophage-, and multi-CSFs. Infect Immun 1988:56:247-51.

36. Matsumoto M, Matsubara S, Matsuno T, et al. Protective effective human granulocyte colonystimulating on microbial infection in neutropenic mice. Infect Immun 1987;55:2715-20.

37. Welte K, Bonilla MA, Gillio AP, et al. Recombinant human granulocyte colony-stimulating factor: Effects on hematopoiesis in normal and cyclophosphamide-treated primates. J Exp Med 1987; 165:941-8.

38. Fushiki M, Ono K, Sasai K. Effect of recombinant human granulocyte colony-stimulating factor on granulocytopenia in mice induced by irradiation. Int J Radiat Oncol Biol Phys 1990;18:353-7.

39. Lang RA, Metcalf D, Cuthbertson RA, et al. Transgenic mice expressing a hematopoietic growth factor gene (GM-CSF) develop accumulations of macrophages, blindness, and a fatal syndrome of tissue damage. Cell 1987;51:675-86.

40. Johnson GR, Gonda DJ, Metcalf D, Hairharon IK, Cory S. A lethal myeloproliferative syndrome in mice transplanted with bone marrow cells infected with a retrovirus expressing granulocytemacrophage colony-stimulating factor. EMBO J 1989;8:441-8.

41. Donahue RE, Wang EA, Stone DK, et al. Stimulation of hematopoiesis in primates by continuous infusion of recombinant human GM-CSF. Nature 1986;321:827-75.

42. Mayer P, Lam C, Obenaus H, Liehe E, Besemer J. Recombinant human GM-CSF induces leukocytosis and activates peripheral blood polymorphonuclear neutrophils in non-human primates. Blood 1987;70:206-13.

43. Nienhuis AW, Donahue RE, Karlsson S, et al. Recombinant human granulocyte-macrophage colony-stimulating factor (GM-CSF) shortens the period of neutropenia after autologous bone marrow transplantation in a primate model. J Clin Invest 1987;80:573-7.

44. Monroy RL, Skelly RR, MacVittie TI, et al. The effect of recombinant GM-CSF on recovery of monkeys transplanted with autologous bone marrow. Blood 1987;70:1696-9.

45. vanderMeer JW, Barza M, Wolff SM, Dinarello CA. A low dose of recombinant interleukin-1 protects granulocytopenic mice from lethal Gram-negative infection. Proc Natl Acad Sci USA 1988;85:1620-3.

46. Fibbe WE, vanderMeer JWM, Falkenburg JHF, et al. A single low dose of human recombinant interleukin- 1 accelerates the recovery of neutrophils in mice with cyclophosphamideinduced neutropenia. Exp Haematol 1989;17:229-34.

47. Bronchud MH, Scarffe JH, Thatcher N, et al. Phase I-II study of recombinant human granulocyte colony-stimulating factor in patients receiving intensive chemotherapy for small cell lung cancer. Br J Cancer 1987;56:809-13.

48. Morstyn G, Campbell L, Lieschke G, et al.
Treatment of chemotherapy-induced neutropenia by subcutaneously administered granulocyte colony-stimulating factor with optimization of dose and duration of therapy. J Clin Oncol 1989;7:1554-62.

49. Lieschke GJ, Maher D, O'Connor M, et al. Phase I study of intravenously administered bacterially synthesized granulocyte-macrophage colonystimulating factor in comparison with subcutaneous administration. Cancer Res 1990;50:606-14.

50. Steward WP, Austin R, Scarffe JH, et al. Phase I study of recombinant DNA granulocyte-macrophage colony-stimulating factor (rGM-CSF). Br J Cancer 1988;57:258.

51. Weisbart RH, Gasson JC, Golde DW. Colonystimulating factors and host defense. Ann Intern Med 1989;1 10:297-303.

52. Cebon J, Dempsey P, Fox R, et al. Pharmacokinetics of human granulocytemacrophage colony-stimulating factor using a sensitive immunoassay. Blood 1988;72:1340-7.

53. Lieschke GJ, Cebon J, Morstyn G. Characterization of the clinical effects after the first dose of a bacterially synthesized recombinant human granulocyte-macrophage colonystimulating factor. Blood 1989;74:2634-43.

54. Lieschke GJ, Maher D, Cebon J, et al. Effects of bacterially synthesized recombinant human granulocyte-macrophage colony-stimulating factor in patients with advanced malignancy. Ann Intern Med 1989; 1 10:357-64.

55. Peters WP, Shogan J, Shpall EJ, et al. Recombinant human granulocyte-macrophage colony-stimulating factor produces fever. Lancet 1988;1:950. (Lett)

56. Drury K, MacFarlane D, Rusthoven JJ. Outpatient supportive care for patients receiving granulocytemacrophage colony-stimulating factor (GM-CSF) with intensive chemotherapy for lung and ovarian cancer. 3rd International Consensus on Supportive Care In Oncology, 1990.

57. Welte K, Zeidler C, Reiter A, et al. Differential effects of granulocyte-macrophage colonystimulating factor and granulocyte colonystimulating factor in children with severe congenital neutropenia. Blood 1990;5:1056-63.

58. Bonilla MA, Gillio AP, Ruggiero M, et al. Effects of recombinant human granulocyte colonystimulating factor on neutropenia in patients with congenital agranulocytosis. N Engl J Med 1989;320:1574-80.

59. Vadhan-Raj S, Jeha SS, Buescher S, et al. Stimulation of myelopoiesis in a patient with congenital neutropenia: Biology and nature of response to recombinant human granulocytemacrophage colony-stimulating factor. Blood 1990;4:858-64.

60. Ganser A, Ottmann OG, Eardmann H, Schultz G, Hoelzer D. The effect of recombinant human granulocyte-macrophage colony-stimulating on neutropenia and related morbidity in chronic severe neutropenia. Ann Intern Med 1989; $111: 887-92$.

61. Lothrop CD, Warren DJ, Souza LM, Jones JA, Moore MAS. Correction of canine cyclic hematopoiesis with recombinant human granulocyte colony-stimulating factor. Blood 
1988;72:1324-8.

62. Negrin RS, Haeuber DH, Negler A, et al. Treatment of myelodysplastic syndromes with recombinant human granulocyte colony-stimulating factor. Ann Intern Med 1989;1 10:976-84.

63. Thompson JA, Lee DJ, Kidd P, et al. Subcutaneous granulocyte-macrophage colonystimulating factor in patients with myelodysplastic syndrome: Toxicity, pharmacokinetics, and hematological effects. J Clin Oncol 1989;7:629-37.

64. Vadhan-Raj S, Keating M, LeMaistre A, et al. The effects of recombinant human granulocytemacrophage colony-stimulating factor in patients with myelodysplastic syndromes. N Engl J Med 1987;317:1545-52.

65. Vadhan-Raj S, Broxmeyer HE, Spitzer G, et al. Stimulation of nonclonal hematopoiesis and suppression of the neoplastic clone after treatment with recombinant human granulocyte-macrophage colony-stimulating factor in a patient with therapy-related myelodysplastic syndrome. Blood 1989:74:1491-8.

66. Glaspy JA, Baldwin GC, Robertson PA, et al. Therapy for neutropenia in hairy-cell leukemia with recombinant human granulocyte colony-stimulating factor. Ann Intern Med 1988; 109:789-95.

67. Groopman JE, Mitsuyasu RT, DeLeo MJ, Oette DH, Golde DW. Effect of recombinant human granulocyte-macrophage colony-stimulating factor on myelopoiesis in the acquired immunodeficiency syndrome. N Engl J Med 1987;317:593-8.

68. Lindemann A, Herrmann F, Oster W, et al. Hematologic effects of recombinant human granulocyte colony-stimulating factor in patients with malignancy. Blood 1989;74:2644-51.

69. Dedhar S, Gaboury L, Galloway P, Eaves C. Human granulocyte-macrophage colonystimulating factor is a growth factor active on a variety of cell types of nonhematopoietic origin. Proc Natl Acad Sci USA 1988;85:9253-7.

70. Berdel WE, Danhauser-Riedl S, Steinhauser G, Winston EF. Various human hematopoietic growth factors (interleukin-3, GM-CSF, G-CSF) stimulate clonal growth of nonhematopoietic tumor cells. Blood 1989;73:80-3.

71. Gabrilove IL, Jakubowski A, Scher H, et al. Effective granulocyte colony-stimulating factor on neutropenia dissociated morbidity due to chemotherapy for transitional-cell carcinoma of the urothelium. N Engl J Med 1988;319:1414-22.

72. Bronchud MH, Howell A, Crowther D, et al. The use of granulocyte colony-stimulating factor to increase the intensity of treatment with doxorubicin in patients with advanced breast and ovarian cancer. Br J Cancer 1989;60:121-5.

73. Neidhart J, Mangalik A, Kohler W, et al. Granulocyte colony-stimulating factor stimulates recovery of granulocytes in patients receiving dose-intensive chemotherapy without bone marrow transplantation. J Clin Oncol 1989; 7:1685-92.

74. Taylor KM, Jagannath S, Spitzer G, et al. Recombinant human granulocyte colonystimulating factor enhances granulocyte recovery after high-dose chemotherapy and autologous bone marrow transplantation in Hodgkin's disease. J Clin Oncol 1989;7:1791-9.

75. Sheridan WP, Wolfe M, Lusk J, et al. Granulocyte colony-stimulating factor and neutrophil recovery after high-dose chemotherapy and autologous bone marrow transplantation. Lancet 1989;ii:891-5.

76. Talmadge JE, Tribble H, Pennington R, et al. Protective, restorative, and therapeutic properties of recombinant colony-stimulating factors. Blood 1989;73:2093-103.

77. Morstyn G, Stewart-Harris R, Bishop J, et al. Optimal scheduling of granulocyte-macrophage colony-stimulating factor (GM-CSF) for the abrogation of chemotherapy-induced neutropenia in small cell lung cancer. Proc Annu Meet Am Soc Clin Oncol 1989;8:850. (Abst)

78. Antman KS, Griffin JD, Elias A, et al. Effective recombinant human granulocyte-macrophage colony-stimulating factor on chemotherapyinduced myelosuppression. N Engl J Med 1988:319:593-8.

79. Gianni AM, Bregni M, Siena S, et al. Recombinant human granulocyte-macrophage colonystimulating factor reduces hematologic toxicity and widens clinical applicability of high-dose cyclophosphamide treatment in breast cancer and non-Hodgkin's lymphoma. J Clin Oncol 1990;8:768-78.

80. Brandt SJ, Peters WP, Atwater SK, et al. Effect of recombinant human granulocyte-macrophage colony-stimulating factor in hematopoietic reconstitution after high-dose chemotherapy and autologous bone marrow transplantation. N Engl J Med 1988;318:869-76.

81. Nadler L, Rabinowe SN. Treatment of lymphoma with ABMT: Role of GM-CSF. Am Soc Hematol Educational symposium, 1989.

82. Rabinowe S, Freedman A, Demetri G, et al. Randomized double-blinded trial of rhuGM-CSF in patients with B-cell non-Hodgkins lymphoma undergoing high-dose chemoradiotherapy and monoclonal antibody purged autologous bone marrow transplantation (ABMT). Blood 1990;76(Suppl 1):161a.

83. Nemunaitis J, Singer JW, Buckner CD, et al. The use of rhGM-CSF for graft failure in patients after autologous, allogeneic, or syngeneic bone marrow transplantation (BMT). Blood 1988;72(Suppl 1): 398a.

84. Nemunaitis J, Singer JW, Buckner CD, et al. Use of recombinant human GM-CSF in autologous bone marrow transplantation for lymphoid malignancies. Blood 1988;72:834-6.

85. Siena S, Bregni M, Brando B, Ravagnani F, Bonadonna G, Gianni AM. Circulation of CD34+ hematopoietic stem cells in the preferred blood of high-dose cyclophosphamide-treated patients: Enhancement by intravenous recombinant human granulocyte-macrophage colony-stimulating factor. Blood 1989; 74:1905-14.

86. Du U, Villeval JO, Boyd J, et al. Effects of recombinant human granulocyte colony-stimulating factor on hematopoietic progenitor cells in cancer patients. Blood 1988;72:2074-81. 


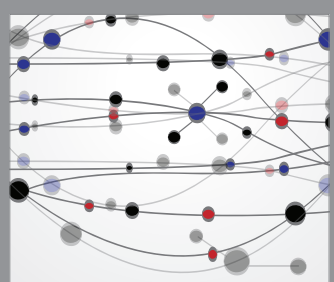

The Scientific World Journal
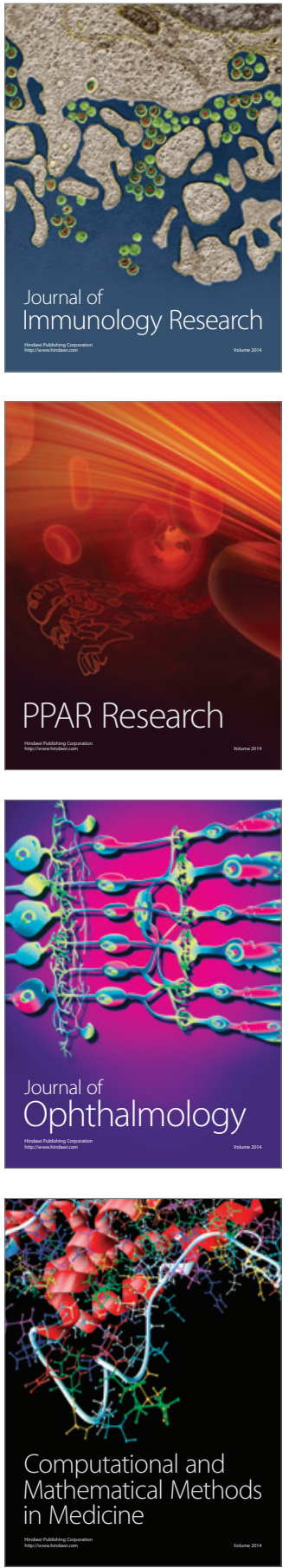

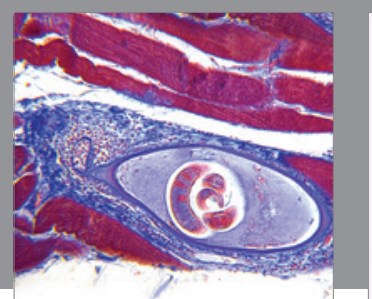

Gastroenterology Research and Practice

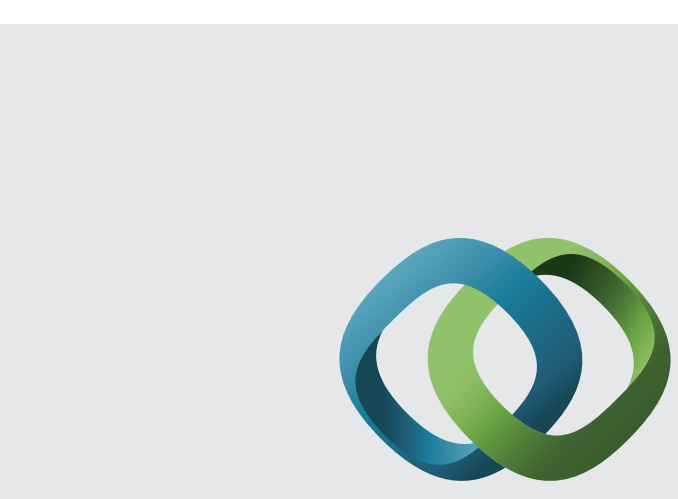

\section{Hindawi}

Submit your manuscripts at

http://www.hindawi.com
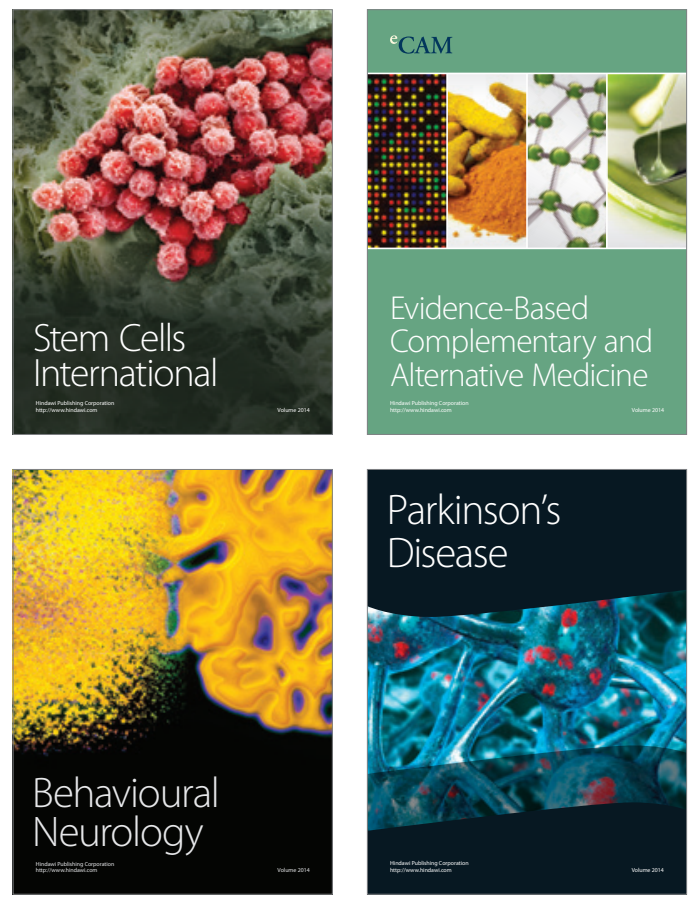
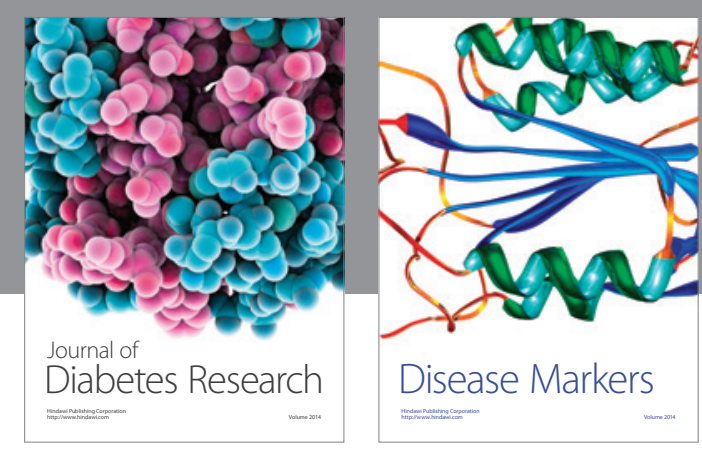

Disease Markers
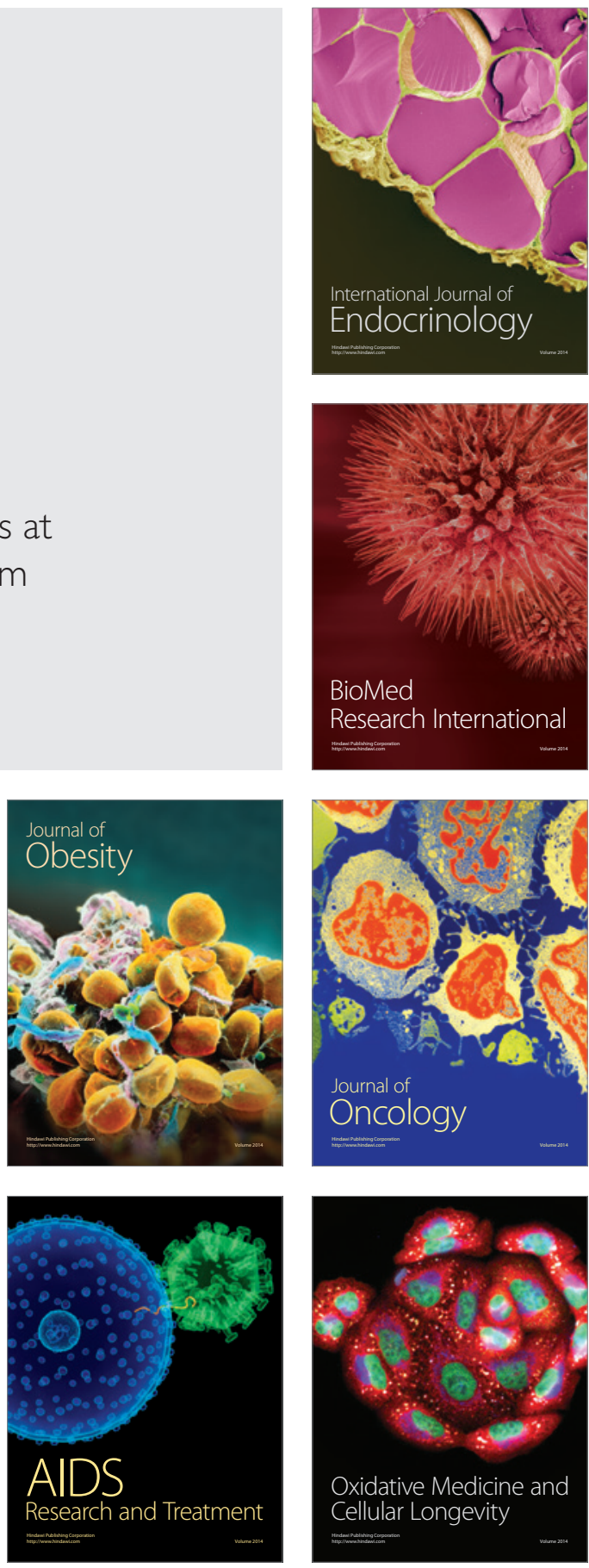